\title{
Manajemen Krisis Destinasi Wisata Pasca Bencana Tsunami Selat Sunda oleh Humas Pemerintah
}

\author{
Putri Widya Oktarini \& Gayatri Atmadi* \\ Program Studi Ilmu Komunikasi, Fakultas Ilmu Sosial \& Ilmu Politik \\ Universitas Al Azhar Indonesia, Jakarta, Indonesia \\ E-mail :widyokta27@gmail.com \\ *Corresponding author: gayatriuai@gmail.com
}

ARTICLE INFO

Article history:

Received

Revised

Accepted
Keywords: crisis management, government public relations, strategy of public relations,sunda strait tsunami, tourist destinations

\section{ABSTRACT}

The purpose of this research is to: (1). Obtained comprehensive descriptions of crisis management conducted in Tanjung Lesung tourist destination after Sunda Strait tsunami natural disaster by The Public Communication Bureau of the Ministry of Tourism. (2). Media options used by the Public Communications Bureau to support crisis management. This study uses an interpretive paradigm method with a qualitative descriptive approach and a case study as research strategy. The method of collecting data in this study was through direct interviews with the Ministry of Tourism's Public Communication Crisis Team. The results showed that the crisis management and strategy carried out was by conducting impact research and news in the media, making programming planning in the form of the appointment of a spokesperson, key public, publishing press releases regularly and organizing events. Besides that, the implementation involved several related communities in disseminating information.

\section{ABSTRAK}

Tujuan penelitian ini untuk :(1). Memperoleh deskripsi komprehensif tentang manajemen krisis yang dilakukan pada destinasi wisata Tanjung Lesung pasca bencana alam Tsunami Selat Sunda oleh Biro Komunikasi Publik Kementerian Pariwisata. (2). Pilihan media yang digunakan Biro Komunikasi Publik untuk menunjang manajemen krisis. Penelitian ini menggunakan metode paradigma interpretif dengan pendekatan penelitian kualitatif deskriptif dan strategi penelitian studi kasus. Metode pengumpulan data dalam penelitian ini melalui wawancara langsung dengan tiga informan dari pihak Tim Krisis Komunikasi Publik Kementerian Pariwisata. Hasil penelitian menunjukan bahwa manajemen krisis dan strategi yang dilakukan adalah dengan melakukan riset dampak serta berita yang ada di media, pembuatan perencanaan pemograman berupa penunjukan juru bicara, publik kunci, publikasi siaran pers secara berkala dan penyelenggaraan event. Selain itu dalam pelaksanaannya melibatkan beberapa komunitas terkait dalam penyebaran informasi
Kata kunci: destinasi wisata, humas pemerintah, manajemen krisis, strategi humas,tsunami selat sunda 


\section{Pendahuluan}

Keberadaan bidang hubungan masyarakat (humas) dalam suatu lembaga atau intansi dapat menjadi jembatan penghubungan antara lembaga tersebut dengan publiknya. Namun, humas juga memiliki peranan yang sangat dibutuhkan dalam bidang pariwisata, khususnya dalam mempromosikan suatu obyek wisata serta menyusun strategi komunikasi untuk kampanye program wisata atau mengelola krisis ketika suatu kawasan wisata mengalami bencana alam yang menelan banyak korban jiwa dan harta benda.

Sektor pariwisata di Indonesia dinaungi oleh lembaga Kementerian Pariwisata Republik Indonesia (Kemenpar RI.). Untuk mendukung agenda kerja dalam promosi destinasi wisata ke manca negara, sejak tahun 2018 Kemenpar memiliki sepuluh destinasi wisata prioritas atau 10 Bali Baru yang dipromosikan dengan bantuan peran dan fungsi humas pemerintah. Salah satu diantaranya adalah obyek wisata di Tanjung Lesung yang berada di Kabupaten Pandeglang, Jawa Barat.

Tanjung Lesung merupakan daerah pesisir yang berlokasi di ujung paling barat pulau Jawa, yaitu : Kabupaten Pandeglang, Banten, Tanjung Lesung merupakan pariwisata pertama dan telah diresmikan beroperasi pada Februari 2015. Dengan pantai yang terkenal akan keindahannya, Tanjung Lesung memiliki kemampuan yang tak kalah dibanding dengan Bali dan Pantai di Jabar lainnya. Buktinya Tanjung Lesung telah berhasil menarik baik wisatawan nasional maupun internasional. Selama tahun 2016 tercatat jumlah kunjungan wisatawan sejumlah 570.000 orang dan ditargetkan meningkat hingga 6,1 juta wisatawan saat beroperasi penuh pada 2020. Bahkan berdasarkan penetapan pemerintahan Jababeka,Tanjung Lesung ditetapkan sebagai salah satu dari 10 New Bali oleh pemerintah Jababeka, juga menjadi salah satu agenda fokus kerja Kementerian Pariwisata. Dalam mendukung rencana pemerintah tersebut perlu dilakukan pembenahan sarana dan prasarana yang disebut dengan Rencana Induk Tanjung Lesung 2020. Selain melakukan pembenahan dan peningkatan infrastruktur sarana dan prasarana, dibuat juga rangkaian acara seni dan budaya, seperti Festival Tanjung Lesung sebagai salah satu bentuk upaya promosi.
Tanjung Lesung diproyeksikan kelak akan menyumbang sebesar satu juta wisman dari target nasional sebesar 20 juta wisman pada 2019.

Namun, masih kuat dalam ingatan kita semua bahwa pada tanggal 22 Desember 2018 pukul 21.27 WIB. terjadi erupsi Gunung Anak Krakatau di kawasan Selat Sunda yang menyebabkan kenaikan air pasang di Laut Jawa sehingga mengakibatkan terjadinya tsunami Selat Sunda yang menerjang lima kabupaten dan daerah pesisir di sepanjang Pantai Carita, Pantai Panimbang, Pantai Teluk Lada, Sumur, dan Tanjung Lesung. Status Tanjung Lesung, Banten sebagai salah satu daerah pasca bencana yang terdampak tsunami Selat Sunda memiliki kerugian sebesar Rp 150 miliar termasuk rusaknya sejumlah puluhan hotel dengan taksiran kerugian hingga 5 miliar rupiah. Bencana ini menjadi ujian berat di tengah upaya pemerintah untuk mendatangkan 20 juta wisman pada 2019. Sebelum dilanda tsunami, tingkat hunian atau okupansi hotel dan penginapan di kawasan wisata Anyer, Carita, dan Tanjung Lesung mencapai 80 $90 \%$.

Dengan adanya kejadian bencana alam seperti ini maka diperlukan kerja keras manajemen krisis Biro Komunikasi Publik Kementerian Pariwisata pada saat pasca tsunami Selat Sunda sebagai usaha yang ditempuh dalam mengembalikan kepercayan pihak luar, khususnya para wisatawan domestik dan mancanegara serta mengembalikan citra Tanjung Lesung sebagai salah satu destinasi wisata yang aman dan nyaman untuk dikunjungi. Penelitian ini bertujuan untuk : (1). Memperoleh deskripsi komprehensif tentang manajemen krisis yang dilakukan untuk destinasi wisata Tanjung Lesung oleh Biro Komunikasi Publik Kementerian Pariwisata. (2). Mengetahui pilihan media komunikasi yang digunakan Biro Komunikasi Publik untuk menunjang aktivitas manajemen krisis.

\section{Review Tinjauan Pustaka}

Scott M Cutlip, Allen H Center, dan Glen M Broom (2013) dalam bukunya Effective Public Relations menjelaskan mengenai pengertian hubungan masyarakat (humas) sebagai fungsi manajemen yang membentuk dan memelihara hubungan yang saling menguntungkan antara organisasi / 
perusahaan dengan masyarakat yang menjadi sandaran keberhasilan atau kegagalannya. Aktivitas humas erat kaitannya dengan persoalan dalam manajemen krisis, apa pun jenis krisisnya. Michael Regester dan Judy Larkin dalam Ayub I. Imran (2017) menjelaskan bahwa krisis merupakan suatu peristiwa yang menyebabkan perusahaan menjadi subjek perhatian luas dari media nasional dan internasional serta kelompokkelompok, seperti pelanggan, pemegang saham, karyawan \& keluarga mereka, para politisi serta kelompok-kelompok lain yang memiliki kepentingan yang dibenarkan terhadap kegiatan-kegiatan organisasi. Beberapa faktor yang menjadi penyebab suatu krisis, diantaranya, yaitu : krisis karena bencana alam, krisis karena kecelakaan industri, krisis karena produk yang kurang sempurna, krisis karena persepsi publik, krisis karena hubungan kerja yang buruk, krisis karena kesalahan strategi bisnis, dan krisis karena terkait masalah kriminal.

Secara sederhana dapat dikatakan bahwa segala upaya dalam manajemen untuk menanggulangi atau mengendalikan krisis hingga pemulihan citra organisasi / perusahaan kembali menjadi baik di mata publik disebut dengan manajemen krisis. Menurut pendapat Fullchis Nurtjahjani (2018), dalam manajemen krisis dibutuhkan peran Public Relations atau hubungan masyarakat, mereka dapat diberikan posisi yang memungkinkan berperan dalam proses merumuskan dan mengimplementasikan strategi menangani krisis dengan mempublikasikan sekumpulan informasi untuk public, baik untuk publik internal maupun untuk publik eksternal.

Scott M Cutlip, Allen H Center, dan Glen M Broom (2013) juga menjelaskan mengenai empat langkah humas dalam memecahkan masalah organisasi / perusahaan, yaitu :

1. Mendefinisikan Problem

Langkah pertama ini mencakup penyelidikan dan pemantauan pengetahuan, opini, sikap dan perilaku pihak-pihak yang terkait dengan, serta dipengaruhi oleh tindakan dan kebijakan organisasi. Pada dasarnya ini adalah fungsi intelijen organisasi. Fungsi ini menyediakan dasar untuk semua langkah dalam proses pemecahan problem dengan menentukan "Apa yang sedang terjadi saat ini?"

2. Perencanaan dan Pemrograman
Informasi yang dikumpulkan dalam langkah pertama akan digunakan untuk membuat keputusan tentang program publik, strategi tujuan, tindakan dan komunikasi, taktik dan sasaran. Proses perencanaan dan pemrograman biasanya menggunakan langkah-langkah berikut, yaitu :

a. Mendefinisikan peran dan misi

b. Menentukan area hasil utama

c. Memilih dan menentukan sasaran

d. Menyiapkan rencana aksi yang meliputi pemrograman, penjadwalan, anggaran, dan komunikasi.

Langkah kedua ini akan menjawab pertanyaan "Berdasarkan apa yang kita tahu tentang situasi, dan apa yang harus kita lakukan atau apa yang kita ubah, dan apa yang harus kita katakan?"

3. Mengambil Tindakan dan Berkomunikasi Langkah ketiga adalah mengimplementasikan program aksi dan komunikasi yang didesain untuk mencapai tujuan program mengenai apa yang akan dikatakan dan apa yang dilakukan. Pertanyaan dalam langkah ini adalah "Siapa yang harus melakukan dan menyampaikan dan kapan, dimana, bagaimana caranya?"

4. Mengevaluasi Program

Langkah terakhir dalam proses ini adalah melakukan penelitian atas persiapan, implementasi, dan hasil dari program. Penyesuaian akan dilakukan sembari program diimplementasikan dan didasarkan pada evaluasi atau umpan balik tentang bagaimana program itu berhasil atau tidak. Program akan dilanjutkan atau dihentikan setelah menjawab pertanyaan "Bagaimana langkah kita sekarang atau seberapa baik langkah yang telah kita lakukan?"

Keempat langkah tersebut di atas bisa dijadikan pedoman dalam menghadapi situasi krisis yang menghadang humas di suatu organisasi / perusahaan. Dalam menjalankan aktivitasnya, bidang humas juga membutuhkan strategi. Firsan Nova (2011) menjelaskan bahwa strategi public relations mencakup tujuh kegiatan penting yang dikenal dengan sebutan bauran Public Relations, yaitu : (1). Publications. Fungsi dari PR adalah meyebarluaskan informasi melalui berbagai media baik cetak maupun online mengenai aktivitas perusahaan yang pantas untuk diketahui oleh publik.(2). Event. Merancang suatu event / acara yang 
bertujuan untuk memperkenalkan produk serta layanan perusahaan atau organisasi, mendekatkan publik dan lebih lanjut lagi dapat mempengaruhi opini publik. (3). News. Menciptakan sebuah berita melalui press release, new letter, bulletin, dan lainlain. (4). Community Involvement. Tugas sehari-hari seorang Public Relations adalah mengadakan kontak sosial dengan kelompok masyarakat tertentu / komunitas guna menjaga hubungan baik dengan pihak organisasi atau perusahaan yang diwakilinya. (5). Inform / Image. Ada dua fungsi utama dari Public Relations, yaitu memberikan informasi kepada publik atau menarik perhatian masyarakat sehingga diharapkan dapat memperoleh tanggapan berupa citra positif. (6). Lobbying and Negotiation. Keterampilan untuk melobi melalui pendekatan pribadi dan kemampuan bernegosiasi sangat diperlu kan bagi seorang PR. Tujuan lobi adalah untuk mencapai kesepakatan atau memperoleh dukungan dari inividu dan lembaga yang berpengaruh terhadap kelangsungan bisnis perusahaan. (7). Social Responsibility. Memiliki tanggung jawab sosial dalam aktivitas pubilc relations menunjukkan bahwa perusahaan memiliki kepedulian terhadap masyarakat.

\section{Metodologi Penelitian}

Paradigma yang digunakan dalam penelitian ini adalah paradigma interpretif karena peneliti ingin mendapatkan pengembangan pemahaman yang membantu proses interpretasi dari suatu peristiwa. Dalam ini, yang menjadi fokus perhatian adalah kegiatan manajemen krisis yang dilakukan oleh bagian humas Kementerian Pariwisata pasca bencana tsunami Selat Sunda di kawasan wisata Tanjung Lesung. Objek penelitian ini adalah Biro Komunikasi Publik Kementerian Pariwisata yang melakukan program-program kerja sebagai upaya startegi manajemen krisis pasca bencana.

Informan dalam penelitian ini adalah tiga staf Biro Komunikasi Publik Kementerian Pariwisata dengan karakteristik informan sebagai berikut: Informan (1) merupakan staf bagian destinasi kepariwisataan yang sudah berkerja selama satu tahun. Informan (2) merupakan staf yang terlibat dalam proses perencanan PR dalam manajemen krisis Tanjung Lesung pasca bencana. Informan (3) merupakan staf yang terlibat langsung dalam pelaksanaan dan penerapan implementasi strategi program manajemen krisis pasca bencana tsunami Tanjung Lesung.

Analisis data kualitatif dimulai dari analisis berbagai data yang berhasil dikumpulkan di lapangan. Data tersebut terkumpul melalui hasil wawancara dan studi dokumen resmi. Kemudian data tersebut diklasifikasikan ke dalam kategori-kategori tertentu. Penulis mengumpulkan data-data yang sudah didapatkan setelah melakukan wawancara, yaitu berupa rekaman wawancara dan studi pustaka. Rekaman wawancara di pindahkan menjadi bentuk transkrip. Kemudian penulis membaca seluruh data secara mendalam dan mengelompokannya berdasarkan jenis-jenis makna untuk memudahkan tahap penafsiran. Tentu saja, analisis data berlangsung ketika data-data yang diperlukan untuk penelitian ini sudah lengkap terkumpul semua. Christine Daymon \& Immy Holloway (2002) menjelaskan bahwa proses analisis data dimulai dari proses koding yang mencakup tiga langkah, yaitu: (1). Koding terbuka. (2). Koding aksial. (3). Koding selektif.

\section{Hasil dan Diskusi}

Kementerian Pariwisata Republik Indonesia (Kemenpar) adalah kementerian yang berada di bawah pertanggung jawaban Presiden. Berdasarkan pada peraturan Menteri Perencanaan Pembangunan Nasional / Kepala Badan Perencanaan Pembangunan Nasional Nomor 5 Tahun 2014 tentang pedoman penyusunan dan penelaahan rencana strategis kementerian / lembaga 2015-2019, visi Kemenpar, yaitu: " Indonesia Menjadi Negara Tujuan Pariwisata Kelas Dunia ".

Berdasarkan visi di atas, terdapat kata kunci visi, yaitu: negara tujuan pariwisata kelas dunia. Definisi dari negara tujuan pariwisata kelas dunia, yaitu: Indonesia menjadi salah satu pilihan utama wisman dan wisnus untuk berwisata dengan destinasi yang didukung oleh atraksi seni dan budaya yang menarik, aksesibilitas yang mudah, dan amenitas yang berkualitas. Berdasarkan misi yang telah ditetapkan oleh Kementerian Pariwisata 2019, maka dapat dirumuskan misi Kementerian Pariwisata, yaitu: (1). Mengembangkan destinasi pariwisata kelas dunia. (2). Melakukan pemasaran dengan berorientasi kepada wisatawan. (3). Mengembangkan 
lingkungan dan kapasitas industri pariwisata yang berdaya saing tinggi. (4). Meningkatkan kapasitas dan kapabilitas kelembagaan pariwisata nasional. (5). Meningkatkan profesionalisme Birokrasi Kementerian Pariwisata melalui reformasi birokrasi.

Dalam melaksanakan tugasnya, Sekretariat Kementerian membawahi tiga biro, salah satu diantaranya adalah Biro Komunikasi Publik (Komblik). Biro Komblik mempunyai tugas, yaitu melaksanakan pengelolaan dan pengembangan informasi publik, publikasi dan pengelolaan media nusantara, serta pengelolaan manajemen krisis kepariwisataan di lingkungan Kementerian.

Dalam melaksanakan tugasnya, Biro Komblik memiliki beberapa fungsi, yaitu: (1). Pelaksa-naan pengelolaan dan pelayanan informasi publik. (2). Pelaksanaan pengelolaan publikasi mancanegara. (3). Pelaksanaan publikasi nusantara dan pengelolaan media. (4). Pelaksanaan manajemen krisis. (5). Pelaksanaan urusan tata usaha biro.

Biro Komunikasi Publik sebagai suatu divisi yang menaungi beberapa divisi lain yang memiliki tugas dalam menyebarkan segala informasi Kementerian pada publik eksternal maupun internal, memiliki program dan kegiatan yang mengacu pada Rencana Tahunan dan Rencanan Strategis Kementerian Biro Komunikasi Publik mempunyai tujuan, yaitu:

a. Mewujudkan citra positif melalui publikasi, pemberitaan, hubungan media massa, pameran, serta analisis berita dan opini publik.

b. Mewujudkan pengelolaan informasi dan dokumentasi, serta layanan informasi publik yang optimal dan terintegrasi.

c. Mewujudkan hubungan yang harmonis, interaktif dan sinergis dengan lembaga negara, dunia usaha serta masyarakat dalam dan luar negeri.

d. Menyediakan dukungan operasionalisasi dan administrasi Pusat Komunikasi Publik yang optimal.

e. Mewujudkan citra positif melalui publikasi, pemberitaan, hubungan media massa, pameran, serta analisis berita dan opini publik.

f. Mewujudkan pengelolaan informasi dan dokumentasi, serta layanan informasi publik yang optimal dan terintegrasi.

g. Mewujudkan hubungan yang harmonis, interaktif dan sinergis dengan lembaga negara, dunia usaha serta masyarakat dalam dan luar negeri.

h. Menyediakan dukungan operasionalisasi dan administrasi Pusat Komunikasi Publik yang optimal.

\section{Tanjung Lesung}

Berlokasi di ujung paling barat Pulau Jawa, yaitu Kabupaten Pandeglang, Banten, KEK Tanjung Lesung merupakan KEK Pariwisata pertama dan telah diresmikan beroperasi pada Februari 2015. KEK Tanjung Lesung memiliki letak yang strategis dan akses yang mudah dijangkau, yaitu $170 \mathrm{~km}$ dari Ibukota Jakarta dan dapat ditempuh melalui perjalanan darat selama 2,5 - 3 jam. KEK Tanjung Lesung memiliki luas area $1.500 \mathrm{Ha}$ dengan potensi pariwisata yang beragam, antara lain keindahan alam pantai, keragaman flora dan fauna serta kekayaan budaya yang eksotis. KEK Tanjung Lesung juga dekat dengan atraksi wisata Banten lainnya seperti Kawasan Tua Banten, Budaya Badui dan Debus, Taman Nasional Ujung Kulon, Gunung Krakatau serta wisata kepulauan. Berasal dari kata "lesung" yaitu alat penumbuk padi tradisional, Tanjung Lesung memiliki bentuk dataran pantai wilayah yang menjorok ke laut dan mirip lesung. Dengan pantai dengan pasir putih serta laut yang jernih, KEK Tanjung Lesung telah menarik baik wisatawan nasional maupun internasional. Selama tahun 2016, Dewan Nasional KEK RI. mencatat jumlah kunjungan wisatawan sebesar 570.000 orang dan ditargetkan meningkat hingga 6,1 juta wisatawan saat beroperasi penuh pada 2020 .

\section{Faktor Krisis Kepariwisataan}

Pengertian krisis menurut pendapat Michael Regester \& Judy Larkin dalam Ayub I.Imran (2017) merupakan sebuah peristiwa yang menyebabkan perusahaan menjadi subjek perhatian luas dari media nasional dan inetrnasional serta kelompok-kelompok seperti pelanggan, pemegang saham, karyawan \& keluarga mereka, para politisi serta kelompokkelompok lain yang memilikikepentingan yang dibenarkan terhadap kgiatan-kegiatan organisasi.

Secara geografis, Indonesia merupakan negara ke pulauan yang terletak pada pertemuan empat lempeng tektonik, yaitu lempeng benua Asia, Australia, lempeng Samudera Hindia dan Samudera Pasifik. Pada bagian selatan dan timur Indonesia terdapat 
sabuk vulkanik, yang sisanya berupa pengunungan vulkanik tua dan dataran rendah. Kondisi tersebut sangat berpotensi sekaligus rawan bencana seperti letusan gunung berapi, gempa bumi, tsunami, banjir dan tanah longsor. Data bnpb.go.id menunjukkan bahwa Indonesia merupakan salah satu negara yang memiliki tingkat kegempaan yang tertinggi di dunia, lebih dari 10 kali lipat tingkat kegempaan di negara lain.

Faktor dari krisis kepariwisataan terbagi menjadi dua faktor pengelompokan berdasarkan Peraturan Menteri Pariwisata Nomor 10 Tahun 2019, ada faktor alam dan non alam. Faktor alam terdiri dari segala hal yang disebabkan oleh bencana alam seperti tanah longsor, letusan gunung api, gerakan tanah atau gempa bumi, tsunami, angin puting beliung, dan bencana alam lainnya. Lalu faktor non alam meliputi situasi yang krisis yang terjadi bukan karena pengaruh alam, seperti politik, kesehatan, seperti wabah atau penyakit menular dan non alam lainnya. Dilihat dari klasifikasi faktor krisis yang telah dipaparkan diatas, bencana alam yang terjadi di Tanjung Lesung, Pandeglang, Banten termasuk kedalam faktor alam karena disebabkan oleh bencana alam erupsi anak Gunung Krakatau yang menyebabkan tsunami pada tanggal 22 Desember 2018, pukul 21.27 WIB.

\section{Krisis Kepariwisataan Tanjung Lesung}

Yulida Medistiara (2018) menjelaskan bahwa kepariwisataan daerah Pandeglang mengalami krisis akibat bencana alam erupsi Gunung Anak Krakatau yang terjadi pada rentang 21-25 Desember 2018 pukul 13.15 WIB. Erupsi Gunung Anak Krakatau yang terjadi di Selat Sunda menyebabkan kenaikan air pasang di laut sehingga terjadi tsunami Selat Sunda yang menerjang lima kabupaten, antara lain : Pandeglang, Serang, Lampung Selatan, Tanggamus dan Pesawaran pada 22 Desember 2018 pukul 21.27 WIB. Selain itu, Taufiq Siddiq (2018) melaporkan untuk tempo.com bahwa daerah pesisir di sepanjang Pantai Carita, Pantai Panimbang, Pantai Teluk Lada, Sumur, dan Tanjung Lesung banyak mengalami kerusakan. 10 kecamatan di Pandeglang terdampak dari terjangan tsunami. Eva Safitri (2018) melaporkan untuk detik.com bahwa Tsunami ini menelan korban sebanyak 437 orang meninggal, 14.059 orang luka-luka dan 16 orang hilang. Jumlah korban dan dampak bencana paling banyak terjadi di
Pandeglang. Tercatat 296 orang meninggal dunia, 7.656 orang luka-luka dan 8 orang hilang. Rully Ramli (2018) melaporkan untuk okezone.com bahwa 8 Ha wilayah KEK mengalami kerusakan dan sejumlah fasilitas yang diantaranya hotel, beach club, dan lagoon.

Maulandy R.B. Kencana (2018) melaporkan untuk liputan6.com bahwa bencana tsunami berdampak pada lumpuhnya sektor wisata andalan di Pandeglang, Banten. Status Tanjung Lesung, Banten sebagai salah satu daerah pasca bencana yang terdampak tsunami Selat Sunda, memiliki pengaruh besar terhadap kunjungan wisatawan, khususnya wisatawan mancanegara. PT Jababeka Tbk selaku pihak pengelola Kawasan Ekonomi Khusus (KEK) Tanjung Lesung melaporkan, telah menderita kerugian sebesar Rp 150 miliar akibat terjangan tsunami. Bencana alam ini terjadi di tengah usaha pemerintah yang baru saja menetapkan Tanjung Lesung sebagai salah satu Kawasan Ekonomi Khusus (KEK) yang menjanjikan sebagai salah satu dari 10 New Bali oleh Kementerian Pariwisata.

\section{Langkah Pertama Manajemen Krisis: Mengidentifikasi Permasalahan Krisis \\ Berdasarkan data yang diperoleh} diketahui bahwa pada saat pertama kali bencana terjadi, pembentukan Tim Krisis kepariwisataan segera dijalankan dengan melibatkan beberapa bagian, termasuk bagian Destinasi yang di dalamnya terbagi menjadi dua tim, dengan satu Tim Krisis kepariwisataan bagian destinasi yang terjun kelapangan langsung untuk melihat dan melakukan pendataan terhadap apa saja dampak terhadap tempat wisata, masyarakat mana saja yang terkena dampak dari bencana sekaligus dengan wisatawan, homestay atau penginapan dan segala perasarana penunjang pariwisata yang terdampak. Selain itu, tim lainnya melakukan media monitoring untuk melihat bagaimana opini publik atau pemberitaan mengenai lokasi wisata yang terkena bencana dan bagaimana informasi yang beredar tentang Tanjung Lesung saat itu. Faktanya menunjukkan bahwa riset opini publik dilakukan pada tahapan kesiap siagaan. Ada pun proses dari riset opini publik yang dilakukan oleh bagian Manajemen Krisis Kepariwisataan/MKK dibagi menjadi beberapa tahapan proses, yaitu dimulai dari jam 9 pagi proses media monitoring untuk 
melihat opini serta pemberitaan mengenai Tanjung Lesung, Banteng saat itu, kemudian selanjutnya jam 12, lalu jam 3 dan kemudian pada jam malam pada pukul 21.00 WIB. Hasil dari rangkuman tersebut selanjutnya diberikan kepada Menteri Pariwisata. Proses riset ini dinamakan pembuatan rangkuman mengenai isu-isu berita, baik dari sisi negatif mau pun sisi positif.

Alasan utama yang mendasari untuk dilakukannya riset oleh Tim Krisis, yaitu untuk menghindari opini hoax yang yang tersebar di media online. Selain itu, proses riset bukan hanya melihat dari media online saja, namun juga melakukan riset opini melalui tanggapan atau pertanyaan masyarakat yang dikirim melalui email resmi MKK dan juga dilibatkan organisasi pariwisata Indonesia, yaitu Visit Indonesia Tourism Officer (VITO), yang langsung mendapatkan akses dalam segalam bentuk informasi terkait bencana saat ini kepada kepala bagian MKK. Pada proses ini juga digunakan suatu alat saring berita yang berhubungan dengan pariwisata di Indonesia. Alat ini juga dapat memudahkan kerja Tim Krisis karena dapat mengumpulkan berita secara cepat dan tepat.

Tim krisis Kementerian Pariwisata Republik Indonesia merupakan satuan unit kerja yang terdiri atas beberapa bagian kerja yang di dalamnya terdiri dari pemantauan dan pecegahan, tim fasilitasi dan penanganan, serta bagian evaluasi dan dokumentasi. Selain itu juga ada beberapa bagian terkait, seperti pemasaran, destinasi dan pihak eksternal, seperti Kementerian Kelautan, BMKG, dan PVMBG.

\section{Langkah Kedua Manajemen Krisis: Perencanaan dan Program Kerja}

Pasca terjadinya tsunami yang menghantam Selat Sunda, Menteri Pariwisata Arif Yahya langsung mengadakan rapat kordinasi yang mengundang beberapa jajaran dari instansi, seperti: BNPB, Gubernur, dan Bupati. Rakor ini diselenggarakan, dalam rangka membuat rapat darurat karena salah satu objek wisata komersil terkena dampak dari bencana. Dalam rakor ini terdapat beberapa pembahasan mengenai banyaknya dampak yang dihasilkan dari bencana tsunami. Hotel atau homestay banyak yang mengalami kerusakan, dan korban yang berjatuhan. Ditengah usaha pemerintah dalam membuat terobosan $10 \mathrm{New}$ Bali. Menpar Arif Yahya mengajak semua instansi, baik Kemenpar dan pihak eksternal yang memiliki keterlibatan dengan area terdampak bencana alam ini, untuk bangkit bersama-sama dengan membuat beberapa program-program.

Hasil dari rakor pemulihan sektor pariwisata pasca tsunami Selat Sunda, terdapat beberapa hal penting yang salah satu diantaranya membahas mengenai: perlunya membuat peta resiko dan rawan bencana Provinsi Banten, termasuk KEK Tanjung Lesung; perlunya dijadikan pedoman pembangunan kepariwisataan berbasis mitigasi dan perlu dilakukan monev secara berkala. Oleh karena itu, dengan diadakannya rapat kordinasi manfaatnya untuk menyatukan pikiran, komitmen dan dukungan manajemen untuk mengembalikan Tanjung Lesung seperti sebelum dihantam bencana dan bahkan lebih baik dari sebelumnya.

Setelah rapat kordinasi maka semua bagian melakukan perannya masing-masing, begitu juga dengan Kemenpar. Pada tahap ini, Kemenpar melakukan beberapa perencanaan pemrograman dengan langkah awal yang dilakukan, yaitu menentukan publik kunci sebagai target sasaran untuk memperbaiki citra Tanjung Lesung dan menarik minat wisatawan. Publik kunci yang ditunjuk, berdasarkan pemaparan dari informan masyarakat yang didalamnya terdapat wisatawan, akademis dan lain-lain. Selain itu, wisman juga menjadi salah satu target dengan menyampaikan informasi melalui pihak perantara, yaitu VITO.

Setelah ditentukan target sasaran yang dituju, selanjutnya Kemenpar menentukan juru bicara yang akan memberikan holding statements pada saat publikasi ke jurnalis dan media sosial karena Tanjung Lesung merupakan wilayah Kawasan Ekonomi Khusus yang siap untuk dipromosikan dan menjadi sorotan dunia. Oleh karena itu, pemilihan juru bicara harus seseorang yang memiliki kredibilitas tinggi dalam pemahaman pada krisis bencana alam Tsunami Selat Sunda. Juru bicara terbagi menjadi dua bidang, yaitu: Juru bicara dari pihak internal Kemenpar dan Juru bicara dari pihak eksternal. Juru bicara internal yang ditunjuk oleh Tim Krisis adalah Kepala Komunikasi Publik dan Bapak Arif Yahya selaku Menteri Pariwisata dan juru bicara dari pihak eksternal adalah Gubernur Banten, Kepala Dinas Pariwisata Banten, BMKG, dan BMPB. 
Setelah ditunjuk juru bicara oleh tim, juru bicara tersebut kemudian menyampaikan beberapa pesan kedalam beberapa tahapan. Pada tahapan awal pasca bencana, pesan yang disampaikan mengenai tempat aman yang bisa wisatawan kunjungi pada saat baru terjadinya bencana dan pemberitahuan mengenai nomor yang bisa dihubungi. Pada tahapan kedua, informan perlu mengeluarkan pernyataan (holding statement) bahwa Tanjung Lesung sudah aman, baik itu aksesnya, amenitas dan akesibilitas (3A). Kemudian, langkah selanjutnya membuat perencanaan program kerja, Kemenpar membuat program kerja pasca bencana untuk daerah yang terdampak maupun yang tidak terdampak, diantaranya : (1). Rapat kordinasi pemulihan wisata pasca bencana; (2). Pemulihan pusat wisata dengan cara membuat kegiatan jambore pokdarwis, festival kuliner kabupaten Pandeglang, seminar workshop opportunity and challenge recreation family business, dan HUT. Pandeglang di alun-alun kota.

Program kerja pemulihan kondisi destinasi wisata Tanjung Lesung menggunakan strategi promosi destinasi wisata melalui pemasaran dengan strategi Branding, Advertising, Selling (BAS). Dalam program branding, dibuat trending topic \#ExcitingBanten untuk program branding Banten yang berhasil diikuti oleh 30.512 post di instagram. Selain itu, dengan strategi advertising, dibuat penayangan iklan di media elektronik, media cetak, media ruang, media digital dan media sosial. Selain itu, ada juga pembuatan berbagai produk promosi, seperti official merchandise dan digital tourism sebagai salah satu bentuk promosi kekinian melalui media sosial dengan menentukan beberapa sudut-sudut menarik sebagai photo spot yang instagramable sehingga dapat menarik perhatian banyak orang, tua dan muda. Yang terakhir, strategi selling dengan cara menyelenggarakan berbagai acara seni dan budaya, tamasya keluarga dan roadshow ke empat kota dalam negeri dan dua kota luar negeri.

Kementerian Pariwisata menyisihkan anggaran kurang lebih sebesar Rp 1M. yang digunakan untuk rehabilitasi kawasan yang terkena dampak bencana alam. Kemudian, dana tersebut akan dialokasikan untuk membantu membangun kembali tempat wisata bencana yang terkena dampak. Dalam pelaksanaannya, pada saat membuat program pasca bencana, pihak Kemenpar tidak melakukan konsultasi dengan pihak eksternal. Semua pembahasan mengenai perencanaan program dibahas dalam internal Kemenpar seperti bagian destinasi, MKK, pemasaran dan Komblik saja.

Langkah Ketiga Manajemen Krisis: Mengambil Tindakan dan Berkomunikasi

Sejak awal 2019, rapat kordinasi dengan gubernur dan dinas pariwisata setempat kerapkali dilakukan hingga akhir 2019. Salah satu dari penyebab krisis terjadi, ialah penyebaran berita tidak benar mengenai suatu topik yang sesungguhnya tidak terjadi, namun memberi dampak atau efek yang tidak diharapkan. Oleh karena itu, untuk menghindari kondisi yang tidak diharapkan maka Tim Krisis merespon segala pemberitaan mengenai Tanjung Lesung, dengan cara memproduksi berita yang bersifat positif atau netral tanpa menyudutkan siapa pun. Hal ini dilakukan untuk dapat mengklarifikasi suatu pemberitaan yang tidak benar tanpa maksud menyerang suatu kelompok yang menyebarkan hoax.

Dalam proses penyebaran informasi, Kemenpar menggunakan cara media ramah bencana sebagai salah satu metode untuk menghindari berita hoax yang bertebaran. Tim Krisis mengundang media forum wartawan pariwisata untuk acara media ramah bencana yang sudah ditetapkan oleh Kemenpar sejak tahun 2019. Belajar dari pengalaman masa lalu saat penyebaran hoax di Palu dan Lombok, Tim Krisis memberitahukan kepada para awak media untuk bekerjasama dalam menulis berita yang tidak hanya dari sisi jeleknya saja, namun juga menampilkan sisi positif supaya dapat meningkatkan citra positif Tanjung Lesung. Yang penting : Jangan menyebar luaskan foto para korban tsunami Selat Sunda secara sembarangan kepada masyarakat. Selain itu, Kemenpar meyakini bahwa dengan membangun hubungan baik dengan para jurnalis media seluruh Indonesia melalui forum wartawan pariwisata bisa jadi upaya mengendalikan penyebaran berita tidak baik atau hoax yang nantinya akan berpengaruh terhadap citra pariwisata di Indonesia, khususnya untuk Tanjung Lesung.

Bagian terakhir dalam tahapan ini, Tim krisis menggunakan beberapa media yang 
digunakan untuk menyebarkan informasi kepada masyarakat secara meluas dan merata. Media yang digunakan dalam memberikan informasi selama krisis, ialah media soal Kementerian Pariwisata (instagram, facebook, youtube dan twitter), website (Kemenpar.go.id), dan menggunakan kanal media digital lainnya serta bekerjasama dengan beberapa wartawan pariwisata di pusat dan di daerah-daerah serta menggunakan VITO untuk area internasional.

\section{Langkah Keempat Manajemen Krisis: Mengevaluasi Program}

Tim Krisis Komblik menggunakan langkah ini sebagai cara untuk untuk melihat seberapa besar keberhasilan program yang dibuat untuk mencapai suatu target yang diharapkan. Dengan adanya evaluasi, dapat memberikan penjelasan secara detail mengenai program kerja apa saja yang sudah baik dan program kerja mana saja yang belum baik dan perlu perbaikan agar bisa mendatangkan manfaat di waktu mendatang. Berdasarkan hasil yang telah dilakukan, disimpulkan bahwa program kerja yang dilaksanakan sudah baik dan efektif serta sesuai dengan kebutuhan yang diharapkan. Selain itu, program yang dibuat sudah mencapai mencapai target yang diharapkan walaupun belum adanya peningkatan secara melonjak namun sudah terlihat adanya kenaikan secara bertahap jumlah wisatawan domestik ke Tanjung Lesung lagi.

Pada tahap normalisasi yang dilakukan berupa produksi serangkaian program acara yang telah dikunjungi oleh beberapa wisatawan yang kemudian di publikasikan lewat media sosial sebagai bentuk promosi untuk menambah rasa percaya masyarakat bahwa destinasi wisata Tanjung Lesung dan sekitarnya sudah aman nyaman dan bisa untuk dikunjungi kembali. Jangka waktu yang diperlukan dalam proses pengembalian citra Tanjung Lesung diperkirakan selama satu tahun sesuai dengan rentang waktu anggaran hingga akhir tahun 2019. Respon masyarakat terhadap Tanjung Lesung kian membaik, dimulai sejak April 2019 tampak adanya peningkatan jumlah wisatawan yang hadir. Walaupun belum terlihat adanya kenaikan jumlah wisatawan secara tajam, namun bisa dikatakan kondisi sudah semakin membaik seiring dengan berjalannya waktu.
Pilihan Media Humas Dalam Menangani Krisis Tsunami Selat Sunda

Untuk mendukung aktivitas manajemen krisis di bidang pariwisata agar dapat mengembalikan citra positif destinasi wisata pasca bencana alam, Tim krisis Komblik Kemenpar memiliki berbagai strategi jitu, diantaranya memanfaatkan hubungan baik dengan para jurnalis media, baik cetak, elektronik maupun digital, memanfaatkan hubungan baik dengan komunitas pecinta jalan-jalan keliling Nusantara, memanfaatkan hubungan baik dengan para investor dan memanfaatkan hubungan baik dengan pemerintah daerah yang berdekatan dengan kawasan Tanjung Lesung.

Tim krisis Komblik Kemenpar memiliki berbagai strategi yang diantaranya melakukan publikasi dengan menggunakan berbagai media komunikasi yang ada, khususnya media sosial., seperti: instagram, facebook dan twiiter. Publikasi ini dilakukan dengan maksud untuk memberikan informasi yang kredibel dan akurat kepada masyarakat mengenai kinerja dari pemerintah daerah yang telah berusaha untuk bersikap terbuka dan transparan. Kemudian, Tim Krisis Komblik membuat calender of event yang dinamakan "100 Calender of Event ". Setelah itu, jadwal beragam acara tersebut dipublikasikan melalui media sosial agar masyarakat dapat mengetahui dan jadi tertarik untuk hadir menyaksikan berbagai acara yang diselenggarakan. Calender of event itu sendiri merupakan kegiatan rutin yang diselenggarakan pada waktu tertentu, seperti acara Hari Ulang Tahun Pandeglang Banten, perayaan hari-hari besar perusahaan dan hari besar lainnya.

Selanjutnya, Kemenpar mempublikasikan Siaran Pers secara berkala pada saat terjadinya bencana mengenai kondisi terkini, tempat yang aman untuk berlindung dan pasca bencana yang merupakan salah satu alat promosi. Dalam strategi ini juga melibatkan komunitas pecinta jalan-jalan, yaitu: Gen WI (Generasi Wonderfull Indonesia), Gen PI (Generasi Pesona Indonesia), Forum wartawan pariwisata yang tersebar di seluruh daerah di Indonesia dan organisasi internasional, yaitu VITO (Visit Indonesia Tourism Officer). 


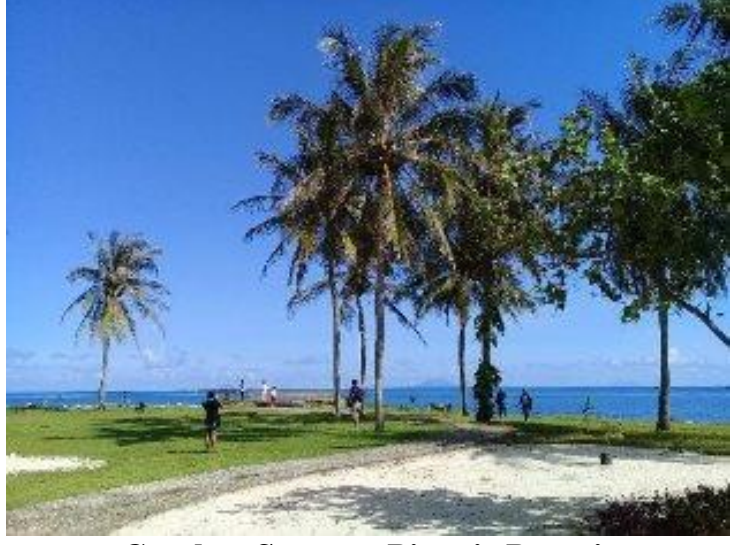

Gambar Suasana Pinggir Pantai

di Tanjung Lesung Beach Hotel \& Resort

(Sumber : Tempo,Bram Setiawan)

\section{Kesimpulan}

Untuk mewujudkan visi Kemenpar dalam meraih Indonesia Menjadi Negara Tujuan Pariwisata Kelas Dunia maka Biro Komunikasi Publik telah melakukan empat langkah manajemen krisis untuk Tanjung Lesung pasca bencana alam tsunami Selat Sunda 2018, yaitu : Pertama, membentuk Tim Krisis lalu mengirim Tim Krisis ke lapangan untuk melihat situasi dampak bencana dan membuat media monitoring. Kedua, mengadakan rapat kordinasi untuk membuat perencanaan penanggulangan berupa penunjukan juru bicara, publik kunci, penyelenggaraan serangkaian acara seni dan budaya, mengatur laju informasi kepada publik demi menghindari hoax dan kegiatan promosi. Ketiga, melaksanakan program kerja yang sesuai dengan perencanaan dan memberikan informasi berupa holding statement dalam bentuk siaran pers kepada masyarakat. Keempat, melakukan evaluasi untuk melihat seberapa baik perencanaan yang telah dilakukan di lapangan.

Singkat kata, program penanganan krisis Selat Sunda yang dilaksanakan sudah terkordinasi dengan baik berkat kerja sama dengan para jurnalis dan sesuai dengan target yang diharapkan walau pun masih belum jelas terlihat adanya peningkatan jumlah wisatawan yang tinggi. Strategi humas yang dilakukan Biro Komunikasi Publik dalam menjalin hubungan baik dengan media, berupa: (1). Meningkatkan intensitas publikasi dengan format media ramah bencana. (2). Membuat beberapa rangkaian acara dalam calender of event di Banten yang dipublikasikan melalui media sosial, yaitu; instagram, facebook dan twiiter. (3). Secara berkala, Kemenpar menyebar luaskan siaran pers yang dipublikasikan melalui berbagai media humas, terutama media sosial, seperti ; instagram, facebook dan twiiter.

\section{Referensi}

[1]. Biro Komunikasi Kemenpar. 2017. Launching Festival Tanjung Lesung. Diakses pada http://www.kemenpar. go.id/post/siaran-pers-launching-festivalpesona-tanjung-lesung-2017.

[2]. Biro Komunikasi Publik. 2016. Laporan Tengah Tahunan Biro Komunikasi Publik T.A 2016. Jakarta: Kementerian Pariwisata.

[3]. Cutlip, Center \& Broom. 2013. Effective Public Relations. Jakarta: Kencana.

[4]. Daymon, Christine \& Immy Holloway. 2002. Metode-Metode Riset Kualitatif dalam Public Relations dan Marketing Communications. Terjemahan. Cahya Wiratama. Yogyakarta: Penerbit Bentang.

[5]. Dewan Nasional KEK RI. 2018. Diakses pada https://kek.go.id/kawasan/TanjungLesung

[6]. Eva Safitri. (2018, Desember31). Update Jumlah Korban Tsunami Selat Sunda: 437 Orang Tewas14.059 Luka. Diakses pada https://news.detik.com/berita/436569/update -jumlah-korban-tsunami-selat-sunda- 437 orang-tewas-14059-luka.

[7]. Fitrah, Muh dan Luthfiyah. 2017. Metodologi Penelitian: Penelitian Kualitatif, Tindakan dan Studi Kasus. Bojong Genteng: CV Jejak

[8]. Imran, Ayub I. 2017. Komunikasi Krisis. Yogyakarta: CV Budi Utama.

[9]. Kek.go.id. 2018. Diakses pada http://kek.go.id/ kawasan/Tanjung-Lesung.

[10]. Kemenpar. 2019. Visi Kementerian Pariwisata. Diakses pada https://www.kemenpar.go.id/page visi-misi

[11]. Mulyana, Deddy. 2006. Metode Penelitian Kualitatif. Bandung: PT Remaja Rosdakarya.

[12]. Nova, Firsan. 2011. Crisis Public Relations. Jakarta: PT Raja Grafindo Persada

[13]. Nova, Firsan. 2014. PR War. Jakarta: Gramedia Widiasarana Indonesia.

[14]. Nugroho, Sutopo Purwo. (2019, Januari 25) Rentannya Pariwisata dari Bencana. Diakses dari https://www.bnpb.go.id/ rentannya-pariwisata-dari-bencana

[15]. Nurtjahjani, Fullchis. 2018. Public Relations Citra \& Praktek. Malang: Polinema Press.

[16]. Rukajat, Ajat. 2018. Pendekatan Penelitian Kualitatif. Yogyakarta: Deepublish. 
[17]. Ruslan, Rosady. 2005. Kiat dan Strategi Kampanye Public Relations. Jakarta: PT. Raja Grafindo Persada.

[18]. Setiawan, Bram. (2019, April 2). Tiga Bulan Pasca Tsunami, Intip Kondisi Terbaru Tanjung Lesung. Diakses pada : google.com/amp/s/ travel.tempo.co

[19]. Supriadi, Bambang dan Nany Roedjinandari. 2017. Perencanaan dan Pengembangan Destinasi Pariwisata. Semarang: Universitas Negeri MalanG

[20]. Tanjung Lesung.com. (2019, April15). Diakses dari https://www.tanjung lesung.com/

[21]. Taufik Siddiq. (2019, April 19). Ada Wilayah Terdampak Tsunami Selat Sunda Belum Dapat Bantuan. Diakses pada https://nasional.tempo.co/read/1158399/adawilayah-terdampak-tsunami-selat-sundabelum-dapat-bantuan/ full\&view=ok. 